\title{
Do HMOs Affect Educational Disparities In Health Care?
}

Kevin Fiscella, $M D, M P H^{1}$

Peter Franks, $M D^{2}$

Mark P. Doescher, MD, MSPH

Barry G. Saver, $M D, M P H^{3}$

'Departments of Family Medicine, and Community and Preventive Medicine,

School of Medicine, University of

Rochester, Rochester, Minn

${ }^{2}$ Department of Family and Community Medicine, School of Medicine, University of California, Davis, Calif

${ }^{3}$ Department of Family Medicine, School of Medicine, University of Washington, Seattle, Wash

\begin{abstract}
BACKGROUND We wanted to examine how membership in a health maintenance organization (HMO) is related to delivery of preventive clinical services to patients with different educational levels.
\end{abstract}

METHODS We conducted a cross-sectional analysis of the 1996-1997 Community Tracking Study Household Survey among adults aged 18 to 64 years with private or Medicaid health insurance. We examined interactions between respondent educational level and HMO membership for the following measures: having a regular source of care and, in the past year, having had a physician visit, a mental health visit, a mammogram (women $\geq 50$ years), an influenza vaccination (ages $\geq 55$ years), or smoking cessation counseling (smokers).

RESULTS After adjustment for sociodemographic factors, community size, insurance type, physical and mental health status, and smoking, respondents with less education were significantly less likely to have had a physician visit or mental health visit, mammogram, or influenza vaccination in the past year. Disparities in receipt of preventive care by educational level were smaller among HMO members. Differences in disparities between HMO members and non-HMO members reached statistical significance for influenza vaccination and showed a trend for mental health visits $(P=.06)$. Moreover, HMO members with less than 12 years of education received services at levels comparable to non-HMO members with more education.

CONCLUSIONS There are appreciable disparities in receipt of preventive care by education among nonelderly insured persons. HMO membership is associated with smaller disparities for some services. Those with the lowest levels of education appeared to benefit the most from HMO membership.

Ann Fam Med 2003;1:90-96. DOI: 10.1370/afm.13.

\section{INTRODUCTION}

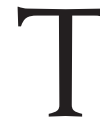

The elimination of disparities in health and health care is a central goal of Healthy People 2010. ${ }^{1}$ Socioeconomic status and race-ethnicity have been linked to standard measures of health care quality. Lower socioeconomic status, often measured by years of education completed, is associated with receiving fewer Papanicolaou smears, mammograms, ${ }^{2,3}$ influenza immunizations, ${ }^{4}$ and diabetic eye examinations, ${ }^{5}$ as well as later enrollment in prenatal care ${ }^{6}$ and lower quality ambulatory ${ }^{7}$ and hospital ${ }^{8}$ care.

Because of a population focus and greater reliance on performance assessment, including accountability to accreditation organizations, ${ }^{9,10}$ health maintenance organizations (HMOs) are potentially positioned to improve health care to persons of low socioeconomic status and reduce disparities among plan members. Yet relatively little is known about the quality of care provided to persons of low socioeconomic status in HMOs or the impact of HMOs on disparities. In earlier studies, Ware and colleagues ${ }^{11,12}$ found that low-income, ill persons fared worse in HMOs than outside HMOs.
CORRESPONDING AUTHOR

Kevin Fiscella, MD, MPH

Highland Family Medicine Center 885 South Ave

Rochester, NY 14620

Kevin_Fiscella@URMC.rochester.edu

ANNALS OF FAMILY MEDICINE + WWW.ANNFAMMED.ORG + VOL. 1, NO. 2 + JULYIAUGUST 2003 
Others studies suggest that $\mathrm{HMO}$ membership has little effect on racial and ethnic disparities in influenza shots and health care utilization measures ${ }^{4,13}$ and might be associated with greater barriers and lower satisfaction for minorities. ${ }^{14}$

Using a large, nationally representative survey, we compared delivery of preventive clinical services among nonelderly adults enrolled in $\mathrm{HMOs}$ with those in non-HMO health care plans. Because HMOs can use population-level quality measures and educational campaigns, we hypothesized that we would observe smaller disparities in the delivery of these services by educational level among $\mathrm{HMO}$ members.

\section{METHODS}

Data are from the Community Tracking Study (CTS) Household Survey conducted in 1996 and $1997 .{ }^{15}$ It is a telephone survey of 60,446 persons representing the US housed, noninstitutionalized population. Sixty communities were randomly selected using stratified sampling with probability in proportion to population size to ensure representation of the US population. While random-digit dialing was used to select most households, a small sample also included households without telephones; these respondents were provided cellular phones for the interviews. Survey data included sociodemographic characteristics, health insurance, health care utilization, health status, and preventive health services. The number of elderly respondents with Medicare who were enrolled in HMOs could not be determined as a result of an error in the original survey; analyses for this study were confined to adults aged 18 to 64 years with insurance (private or Medicaid). The final response rate for the CTS Household Survey was $65 \%$. A total of 31,676 nonelderly adult respondents comprised the sample for the study.

Regular source of care; likelihood of a physician visit, mental health visit, mammogram, or influenza vaccination in the past year; and receipt of smoking cessation counseling were each modeled as a function of HMO membership and patient educational level. Interactions by insurance type were also modeled. Covariates, described below, were selected using the Andersen-Aday behavioral model that identifies predisposing, enabling, and need factors. ${ }^{16}$

\section{Primary Independent Variables}

Education (Predisposing). Data were collected regarding respondents' education (less than 12 years of completed education, 12 years, 13-15 years and 16 or more).

Insurance (enabling). This was classified as private or Medicaid.
HMO membership (enabling). This was based on the respondents' responses to a survey item asking whether their plan was an $\mathrm{HMO}$ or not.

\section{Covariates}

Race, Ethnicity, Language (Predisposing). The following 5 , mutually exclusive categories were based on the respondent's self-identification and the language in which the interview was conducted: white black$_{i}$ Hispanic, English fluent ${ }_{i}$ Hispanic, non-English fluent ${ }_{i}$ and other race.

Demograpbic characteristics (predisposing). These categories include age ( 18 to 29,30 to 44 , and 45 to 64 years, but entered as a continuous variable in analyses of mammography and influenza vaccination, where the sample was limited to older adults), sex, marital status (married or not), family size, community size (large metropolitan region of more than 200,000 population, small metropolitan region of less than 200,000 population, or nonmetropolitan region), and household income (as a percentage of the federal poverty level for 1996 : less than $100 \%$; $100 \%$ to $199 \%$; $200 \%$ to $299 \%$; $300 \%$ to $399 \%$; more than $400 \%$ ).

Health status (need). We used self-reported health status as a proxy for need. Health status was assessed based on the Medical Outcomes Study Short Form 12 -item health survey (SF-12). It includes 2 summary scores, 1 for physical health (range, $10-69$; mean, 52 in this sample) and 1 for mental health (range, $8-71$; mean, 51 in this sample). It has been shown to be reliable and valid compared with the well-established, longer SF-36. ${ }^{17,18}$

Smoking status (predisposing). Respondents were asked whether they currently smoked, formerly smoked, or never smoked.

\section{Dependent Variables}

We used standard dichotomous measures for medical, mental health, and preventive health services use.

Having a Regular Source of Care. This variable was dichotomous ("Is there a place you usually go when you are sick, or need advice about your health?") This measure was also included as an independent covariate in analyses of the remaining dependent variables.

Physician Visit. This measure was based on a respondent report of at least 1 physician visit in the past year.

Mental Health Visit. This measure was based on the respondents report that they had "seen or talked to a mental health professional such as a psychiatrist, psychologist, psychiatric nurse, or clinical social worker" in the past year.

Mammography. Respondents were asked whether they had received a mammogram in the past year 
(women older than 50 years, $\mathrm{n}=7,418$ for this subsample).

Influenza Vaccination. Respondents were asked whether they had received an influenza vaccination in the past year (adults 55 years and older, $\mathrm{n}=4,277$ for this subsample).

Smoking Cessation Counseling. Respondents who smoked were asked whether they had been counseled by their physician to quit smoking (adult smokers, $\mathrm{n}=7,488$ for this subsample).

\section{Analysis}

We conducted analyses using the statistical software package SUDAAN ${ }^{19}$ to account for the complex design of the CTS Household Survey. ${ }^{15}$ We compared $\mathrm{HMO}$ and non-HMO members overall and within each educational stratum.

Separate logistic regression models were developed for having a usual source of care (all) and receipt in the past year of at least 1 physician visit (all), at least 1 visit with a mental health professional (all), smoking cessation counseling (all smokers), mammography (women 50 years and older), and an influenza vaccination (all 55 years and older). We assessed for interaction between HMO status and education and also evaluated interactions between HMO status and income, race and ethnicity, and Medicaid insurance. To facilitate ease of interpretation of the size of the education and $\mathrm{HMO}$ effects, adjusted predicted marginal effects were calculated. ${ }^{20}$

\section{RESULTS}

The characteristics of respondents in HMOs and not in HMOs are shown in Table 1. In bivariate analyses, $\mathrm{HMO}$ members were more likely to be younger, male, single, minority, and more educated, have a higher income, have private insurance as opposed to Medicaid, reside in a large metropolitan area, and have better physical health status. Higher educational attainment was significantly associated with greater likelihood of having a usual source of care, a physician visit, mental health visit, mammogram, and influenza vaccination (Table 2). Adjustment resulted in loss of significance for having a usual source of care but had little effect on educational disparities for the other measures. Statistically significant differences in the likelihood of having a mental health visit in the last year by educational level increased after adjustment. Interestingly, there was no association of education with receipt of smoking cessation advice.

Table 3 shows crude (bivariate) and adjusted associations of health care access and use with HMO membership. Following adjustment for race-ethnicity-lan-

\section{Table 1. Characteristics of Health Maintenance Organization (HMO) vs Non-HMO Members Among Nonelderly, Insured Adults}

\begin{tabular}{|c|c|c|}
\hline Characteristic & $\begin{array}{c}\text { HMO } \\
(\mathrm{n}=15,006) \\
\%(95 \% \mathrm{Cl})\end{array}$ & $\begin{array}{c}\text { Non-HMO } \\
(\mathrm{n}=16,670) \\
\%(95 \% \mathrm{Cl})\end{array}$ \\
\hline \multicolumn{3}{|l|}{ Education, years* } \\
\hline$<12$ & $9.7(8.7-10.7)$ & $11.1(10.3-11.9)$ \\
\hline 12 & $33.7(32.7-34.7)$ & $33.6(32.4-34.8)$ \\
\hline $13-15$ & $29.5(28.5-30.5)$ & $27.5(26.3-28.7)$ \\
\hline$\geq 16$ & $27.1(26.1-28.1)$ & $27.8(26.8-28.8)$ \\
\hline \multicolumn{3}{|l|}{ Age, years $^{\dagger}$} \\
\hline $18-29$ & $24.0(23.0-25.0)$ & $21.9(20.9-22.9)$ \\
\hline $30-44$ & $44.2(43.2-45.2)$ & $41.1(40.9-42.3)$ \\
\hline $45-64$ & $31.8(31.7-31.8)$ & $37.0(35.8-38.2)$ \\
\hline Male sex ${ }^{\ddagger}$ & $49.0(48.2-49.8)$ & $48.1(47.5-48.7)$ \\
\hline \multicolumn{3}{|l|}{ Race $^{\dagger}$} \\
\hline Black & $12.8(10.8-14.8)$ & 9.7 (7.7-11.7) \\
\hline Hispanic, English fluent & $7.9(5.9-9.9)$ & $4.2(3.0-5.4)$ \\
\hline Hispanic, non-English fluent & $4.2(3.8-4.6)$ & $2.5(1.3-3.7)$ \\
\hline Other race & $6.2(5.4-7.0)$ & $4.8(4.2-5.4)$ \\
\hline White & $68.9(67.7-70.1)$ & $78.9(77.7-80.1)$ \\
\hline Marital status, single* & $37.9(36.5-39.3)$ & $35.4(33.8-37.0)$ \\
\hline $\begin{array}{l}\text { Mean family size } \\
2.76)\end{array}$ & $2.66(2.62-2.70)$ & $2.70(2.64-$ \\
\hline \multicolumn{3}{|l|}{ Residence $^{\dagger}$} \\
\hline Large metropolitan area & $82.3(79.5-85.1)$ & $66.6(62.6-70.6)$ \\
\hline Small metropolitan area & $4.3(3.5-5.1)$ & $7.5(6.5-8.5)$ \\
\hline Nonmetropolitan area & $13.3(10.7-15.9)$ & $25.9(22.5-29.3)$ \\
\hline Medicaid insurance $^{\dagger}$ & $3.3(2.7-3.9)$ & $8.0(7.0-9.0)$ \\
\hline \multicolumn{3}{|l|}{ Smoking status } \\
\hline Current & $25.3(24.3-26.3)$ & $24.9(23.7-26.1)$ \\
\hline Former & $21.6(20.6-22.6)$ & $22.4(21.4-23.4)$ \\
\hline Never & $53.1(51.5-54.7)$ & $54.2(52.6-55.8)$ \\
\hline \multicolumn{3}{|l|}{ Health status } \\
\hline PCS 12 (physical) score, mean $\S$ & $51.1(50.9-51.3)$ & $50.8(50.6-51.0)$ \\
\hline MCS 12 (mental) score, mean & $52.3(52.1-52.5)$ & $52.3(52.1-52.5)$ \\
\hline \multicolumn{3}{|l|}{$\begin{array}{l}\text { Income as percent } \\
\text { of poverty level }{ }^{\dagger}\end{array}$} \\
\hline$<100 \%$ & 14.0 (13.0-15.0) & $17.2(16.0-18.4)$ \\
\hline $100 \%-199 \%$ & $18.1(16.9-19.3)$ & $16.7(15.7-17.7)$ \\
\hline $200 \%--399 \%$ & $36.0(34.8-37.2)$ & $33.3(32.1-34.5)$ \\
\hline$\geq 400 \%$ & $31.9(30.3-33.5)$ & $32.8(31.6-34.4)$ \\
\hline \multicolumn{3}{|c|}{$\begin{array}{l}* P<.01 . \\
\dagger P<.001 . \\
\ddagger P<.05 . \\
\S \text { Higher scores on the physical health summary score (PCS 12) and the mental } \\
\text { health summary score (MCS 12) of the Medical Outcomes Study Short Form } 12 \\
\text { health survey indicate better physical or mental health status. }\end{array}$} \\
\hline
\end{tabular}

guage, age, sex, income, marital status, family size, community size, smoking and health status, HMO members were more likely to have a usual source of care, a physician visit, mammogram, and influenza vaccination.

Significant interactions were found between HMO status and educational attainment for influenza vaccination and smoking $;$ there was evidence of a trend 
$(P=.06)$ for mental health visits (Table 4). Educational disparities were narrowed for influenza vaccination and mental health visits within HMOs. For smoking cessation counseling, $\mathrm{HMO}$ members with less than 12 years of education were more likely to receive counseling than persons with more than 16 years of education. In contrast, there was little difference among non-HMO members. A careful review of Table 4 shows that in each instance, those with the least education fared better if they were $\mathrm{HMO}$ members. This effect was less consistent among those with

\section{Table 2. Relationship Between Education and Health Care Access and Use}

\begin{tabular}{|c|c|c|}
\hline Characteristic & $\begin{array}{c}\text { Crude Prevalence } \\
\quad \%(95 \% \mathrm{Cl})\end{array}$ & $\begin{array}{c}\text { Adjusted } \\
\text { Prevalence* } \\
\%(95 \% \mathrm{Cl})\end{array}$ \\
\hline $\begin{array}{l}\text { Has usual source } \\
\text { of care }\end{array}$ & $P=.0001$ & $P=.45$ \\
\hline$<12$ years & $82.9(80.8-85.0)$ & $85.3(83.4-87.2)$ \\
\hline 12 years & $85.3(84.4-86.2)$ & $86.0(85.2-86.8)$ \\
\hline $13-15$ years & $86.9(85.8-88.0)$ & $86.8(85.7-87.9)$ \\
\hline$\geq 16$ years & $87.1(86.3-87.9)$ & $86.0(85.1-86.9)$ \\
\hline $\begin{array}{l}\text { Physician visit } \\
\text { in past year }\end{array}$ & $P<.0001$ & $P<.0001$ \\
\hline$<12$ years & $72.3(70.1-74.5)$ & $72.5(70.6-74.3)$ \\
\hline 12 years & $76.0(75.2-76.8)$ & $76.5(75.7-77.3)$ \\
\hline $13-15$ years & $79.8(78.8-80.8)$ & $79.1(78.1-80.1)$ \\
\hline$\geq 16$ years & $81.3(80.3-82.3)$ & $81.2(80.2-82.2)$ \\
\hline $\begin{array}{l}\text { Mental health visit } \\
\text { in past year }\end{array}$ & $P=.0001$ & $P<.0001$ \\
\hline$<12$ years & $7.5(6.3-8.7)$ & $5.3(4.4-6.2)$ \\
\hline 12 years & $6.7(6.1-7.3)$ & $6.5(5.9-7.1)$ \\
\hline $13-15$ years & $8.6(7.8-9.4)$ & $8.7(8.0-9.4)$ \\
\hline$\geq 16$ years & $8.6(8.0-9.2)$ & $10.1(9.4-10.8)$ \\
\hline $\begin{array}{l}\text { Mammogram } \\
\text { in past year }\end{array}$ & $P<.0001$ & $P=.005$ \\
\hline$<12$ years & $54.3(49.8-58.8)$ & $57.0(52.5-61.5)$ \\
\hline 12 years & $61.8(59.4-64.2)$ & $62.7(60.3-65.1)$ \\
\hline $13-15$ years & $64.0(60.7-67.3)$ & $63.4(60.0-66.8)$ \\
\hline$\geq 16$ years & $69.7(66.8-72.6)$ & $67.5(64.5-70.5)$ \\
\hline $\begin{array}{l}\text { Influenza vaccination } \\
\text { in past year }\end{array}$ & $P=.0001$ & $P=.0002$ \\
\hline$<12$ years & $27.1(22.7-31.5)$ & $27.7(23.8-31.6)$ \\
\hline 12 years & $37.5(33.9-41.1)$ & $36.5(32.9-40.1)$ \\
\hline $13-15$ years & $36.2(32.7-39.7)$ & $36.0(32.0-40.0)$ \\
\hline$\geq 16$ years & $39.6(36.2-43.0)$ & $40.9(37.2-44.6)$ \\
\hline $\begin{array}{l}\text { Smoking cessation } \\
\text { advice }\end{array}$ & $P=.13$ & $P=.31$ \\
\hline$<12$ years & $50.8(46.6-55.0)$ & $49.1(45.0-53.2)$ \\
\hline 12 years & $47.4(45.0-49.8)$ & $48.0(45.6-50.4)$ \\
\hline $13-15$ years & $47.3(44.5-50.1)$ & $47.2(44.4-50.0)$ \\
\hline$\geq 16$ years & $44.4(41.0-47.8)$ & $44.4(41.0-47.8)$ \\
\hline
\end{tabular}

* Multivariate analyses adjusted for race-ethnicity, age, sex, income, marital status, family size, community size, smoking, mental health summary score (MCS 12 ) and physical health summary score (PCS 12) of the Medical Outcomes Study Short Form 12, insurance type (private; Medicaid), health maintenance organization status, and usual source of care.

\section{Table 3. Relationship Between Health Maintenance Organization (HMO) Status and Health Care Access and Use}

\begin{tabular}{|c|c|c|}
\hline Characteristic & $\begin{array}{c}\text { Crude Prevalence } \\
\%(95 \% \mathrm{Cl})\end{array}$ & $\begin{array}{l}\text { Adjusted } \\
\text { Prevalence* } \\
\%(95 \% \mathrm{CI})\end{array}$ \\
\hline $\begin{array}{l}\text { Has usual source } \\
\text { of care }\end{array}$ & $P<.0001$ & $P<.0001$ \\
\hline HMO & $87.5(86.7-88.3)$ & $88.1(87.4-88.9)$ \\
\hline Not HMO & $84.7(83.9-85.5)$ & $84.4(83.6-85.2)$ \\
\hline $\begin{array}{l}\text { Physician visit } \\
\text { in past year }\end{array}$ & $P=.0005$ & $P=.001$ \\
\hline HMO & $79.4(78.4-80.4) 7$ & $9.1(78.3-79.9)$ \\
\hline Not HMO & $77.1(76.3-77.9)$ & $77.4(76.8-78.0)$ \\
\hline $\begin{array}{l}\text { Mental health visit } \\
\text { in past year }\end{array}$ & $P=.95$ & $P=.92$ \\
\hline HMO & $7.8(7.3-8.3)$ & $7.8(7.3-8.3)$ \\
\hline Not HMO & $7.8(7.3-8.3)$ & $7.8(7.3-8.3)$ \\
\hline $\begin{array}{l}\text { Mammogram in } \\
\text { past year }\end{array}$ & $P=.09$ & $P=.02$ \\
\hline $\mathrm{HMO}$ & $64.8(62.3-67.3)$ & $65.3(62.8-67.8)$ \\
\hline Not HMO & $62.0(60.1-63.9)$ & $61.6(59.7-63.5)$ \\
\hline $\begin{array}{l}\text { Influenza vaccination } \\
\text { in past year }\end{array}$ & $P=.24$ & $P=.01$ \\
\hline HMO & $37.3(33.2-41.4)$ & $38.5(35.0-42.0)$ \\
\hline Not HMO & $35.0(32.8-37.2)$ & $34.3(31.8-36.9)$ \\
\hline $\begin{array}{l}\text { Smoking cessation } \\
\text { advice }\end{array}$ & $P=.50$ & $P=.39$ \\
\hline HMO & $47.9(45.8-50.0)$ & $48.0(45.8-50.2)$ \\
\hline Not HMO & $47.00(45.0-49.0)$ & $46.9(44.8-49.0)$ \\
\hline \multicolumn{3}{|c|}{$\begin{array}{l}\text { * Multivariate analyses adjusted for race-ethnicity, age, sex, income, marital status, } \\
\text { family size, community size, smoking, mental health summary score (MCS 12) and } \\
\text { physical health summary score (PCS 12) of the Medical Outcomes Study Short } \\
\text { Form 12, insurance type (private; Medicaid), HMO status, and usual source of care. }\end{array}$} \\
\hline
\end{tabular}

higher education. With the exception of having a usual source of care and smoking cessation counseling; however, persons with lower educational attainment continued to fare worse than those with more education even within HMOs.

There were few other statistically significant interactions. Respondents with Medicaid HMO membership had significantly higher likelihood of smoking cessation counseling than respondents with Medicaid in fee-for-service practices or respondents with private $\mathrm{HMO}$ or non-HMO coverage. Notably, there were no significant interactions between $\mathrm{HMO}$ membership and race-ethnicity (including non-English-fluent Hispanics) for any of the health care utilization measures, suggesting that $\mathrm{HMO}$ membership had no differential effect on care for minorities. There was also no interaction between $\mathrm{HMO}$ membership and income.

\section{DISCUSSION}

In a nationally representative sample of nonelderly, insured adults, we found significant disparities by 
patient educational attainment in use of health care. Persons with less education were significantly less likely to have had a physician or mental health visit, a mammogram, or an influenza vaccination within the last year. Consistent with previous studies, ${ }^{21-23}$ we found that HMO membership was associated with an overall beneficial effect on care. Most importantly, those with the least education tended to show improved use when in HMOs. In particular, $\mathrm{HMO}$ members with less than 12 years of education received services at levels comparable to non-HMO respondents with more education. Disparities were significantly smaller for influenza vaccination. The least educated smokers enrolled in HMOs reported the highest likelihood of smoking cessation counseling of any group. In no instance were educational disparities worse in HMOs.

To our knowledge, this study is first to examine specifically the impact of HMOs on educational disparities in health care utilization using nationally representative data. Previously reported results showed an absence of any apparent effect of HMOs on racial and ethnic disparities ${ }^{4}$ and an apparently harmful effect on health outcomes for ill persons of low socioeconomic status. ${ }^{11-13}$ Our findings suggest that HMOs might have modest beneficial effects on at least some educational disparities in care.

These findings should be tempered by the limitations of the study. All data were based exclusively on self-report. There is some inaccuracy in self report of $\mathrm{HMO}$ membership ; among privately insured persons in the CTS Household Survey, self-report of HMO membership had a sensitivity of $73 \%$ and specificity of $78 \% .{ }^{24}$ Educational bias in reporting HMO membership alone, however, could not account for these findings. Only if educational bias in reporting $\mathrm{HMO}$ membership were correlated with a bias in reporting use of services would such a bias explain these findings. Available evidence suggests that self-report of receipt of preventive services appears to be a sensitive, but not specific, measure of actual receipt of the service. ${ }^{25,26}$ It is important to note that there does not appear to be educational bias in reporting. ${ }^{27,28}$ Thus, it appears unlikely that these results are primarily attributable to reporting bias.

Our data are now more than 5 years old. Considerable changes have occurred in managed care during this period. ${ }^{29}$ The extent to which these findings hold today is uncertain.

These analyses examined a limited array of health care indicators, mostly associated with prevention. We were not able examine educational disparities in care for chronic conditions or health outcomes. Thus, our findings and those from previous studies that sug- gest HMOs might adversely affect the health status of poorer, sicker patients are not directly comparable. ${ }^{11,12}$ Also, although we controlled for differences in the characteristics of HMO and non-HMO members, it is possible that unmeasured characteristics, such as attitudes about health care, differed between the 2 groups.

Our analyses did not account for differences in types of HMOs. It is possible that different types of HMOs have differing effects on disparities. Our analyses also did not account for HMO profit status. Not-

\section{Table 4. Adjusted Prevalence of Health Care Access and Use by Education and Health Maintenance Organization (HMO) Status}

\begin{tabular}{|c|c|c|}
\hline Educational Level & In HMO & Not in HMO \\
\hline \multicolumn{3}{|l|}{$\begin{array}{l}\text { Has usual source of } \\
\text { care, } P=.83^{*}\end{array}$} \\
\hline$<12$ years & 86.7 (83.9-89.5) & $83.9(81.7-86.1)$ \\
\hline 12 years & 87.9 (86.8-89.0) & $84.4(83.2-85.6)$ \\
\hline $13-15$ years & $88.8(87.5-90.2)$ & $84.9(83.4-86.4)$ \\
\hline$>16$ years & $88.1(86.9-89.3)$ & $84.2(82.9-85.5)$ \\
\hline \multicolumn{3}{|l|}{$\begin{array}{l}\text { Physician visit in past } \\
\text { year, } P=.52^{*}\end{array}$} \\
\hline$<12$ years & 74.6 (71.3-77.9) & $70.9(68.6-73.2$ \\
\hline 12 years & 77.4 (76.1-78.7) & $75.6(74.4-76.8)$ \\
\hline $13-15$ years & 80.2 (78.9-81.5) & $78.3(76.9-79.7)$ \\
\hline$>16$ years & $81.5(80.1-82.9)$ & $81.0(79.8-82.2)$ \\
\hline \multicolumn{3}{|c|}{$\begin{array}{l}\text { Mental health visit } \\
\text { in past year, } P=.06^{*}\end{array}$} \\
\hline$<12$ years & $6.1(4.6-7.6)$ & $4.8(3.8-5.8)$ \\
\hline 12 years & $6.7(6.0-7.4)$ & $6.3(5.4-7.2)$ \\
\hline $13-15$ years & $9.0(8.0-10.0)$ & $8.4(7.5-9.3)$ \\
\hline$>16$ years & $9.2(8.2-10.2)$ & 10.7 (9.7-11.7) \\
\hline \multicolumn{3}{|l|}{$\begin{array}{l}\text { Mammogram in past } \\
\text { year, } P=.77^{*}\end{array}$} \\
\hline$<12$ years & $61.5(53.4-69.6)$ & $53.9(47.2-60.6)$ \\
\hline 12 years & 65.5 (61.5 69.5) & $60.7(57.3-64.1)$ \\
\hline $13-15$ years & 64.5 (59.3-69.7) & $62.8(58.2-67.4)$ \\
\hline$>16$ years & $68.6(63.2-74.0)$ & $66.8(63.3-70.3)$ \\
\hline \multicolumn{3}{|c|}{$\begin{array}{l}\text { Influenza vaccination } \\
\text { in past year, } P=.04^{*}\end{array}$} \\
\hline$<12$ years & $31.7(25.6-37.8)$ & $25.3(20.0-30.6)$ \\
\hline 12 years & $35.5(31.1-39.9)$ & $37.1(32.9-41.3)$ \\
\hline $13-15$ years & $39.7(33.6-45.8)$ & $33.8(29.0-38.6$ \\
\hline$>16$ years & $47.3(41.8-52.8)$ & $37.0(32.7-41.3)$ \\
\hline \multicolumn{3}{|l|}{$\begin{array}{l}\text { Smoking cessation } \\
\text { advice, } P=.01^{*}\end{array}$} \\
\hline$<12$ years & $54.3(48.3-60.3)$ & $44.9(39.4-50.4)$ \\
\hline 12 years & $47.3(44.0-50.6)$ & $48.7(45.5-51.9)$ \\
\hline 13-15 years & $49.4(46.0-52.8)$ & $45.3(41.5-49.1)$ \\
\hline$>16$ years & $41.9(37.0-46.8)$ & $46.8(42.5-51.1)$ \\
\hline \multicolumn{3}{|c|}{$\begin{array}{l}\text { Note: Multivariate analyses adjusted for race-ethnicity, age, sex, income, marital sta- } \\
\text { tus, family size, community size, smoking, mental health summary score (MCS 12) } \\
\text { and physical health summary score (PCS 12) of the Medical Outcomes Study Short } \\
\text { Form 12, insurance type (private; Medicaid), HMO status, and usual source of care. } \\
\text { * P values represent tests for significance for interaction between HMO member- } \\
\text { ship and educational level. }\end{array}$} \\
\hline
\end{tabular}


for-profit HMOs have been shown to deliver higher quality care than investor-owned HMOs in areas measured by Health Plan Employer Data and Information Set (HEDIS) indicators. ${ }^{30}$ Clearly, differences among HMOs warrant further examination, because strengthening those kinds of $\mathrm{HMOs}$ that have a more beneficial effect on disparities represents a possible policy option for reducing disparities

Although disparities tended to be smaller in HMOs, in most cases these disparities were not eliminated by HMO membership. Thus, there is ample opportunity for quality improvement. HMOs, by virtue of their population focus and reporting through the HEDIS, are better positioned than non-HMO plans to address disparities in care. Before they can begin to do so directly, however, they will need to begin collecting race, ethnicity, and education data on their members and begin stratifying their HEDIS performance measures by race-ethnicity and educational status. ${ }^{31}$ Once determined, these disparities can be targeted through quality improvement efforts using various approaches, ${ }^{32}$ including reminder letters ${ }^{33,34}$ and case management. ${ }^{35}$

We can only speculate about explanations for our findings. It is possible that lower copayments improve access to influenza vaccination within HMOs. It is also possible that $\mathrm{HMO}$ physicians are targeting their efforts toward members who have higher rates of smoking ${ }^{36}$ and who are at higher risk because of their lower educational status. ${ }^{37}$ Planwide interventions undertaken by HMOs to boost use of influenza immunizations, such as reminders to patients, might provide slightly greater benefit to patients who are less aware of the potential benefits of these services. At least among the elderly, health literacy might be even more important than educational level in promoting use of preventive care.$^{38}$ It is possible that HMOs more effectively promote use of these services among this population. Alternatively, given the relatively small observed effect sizes, it is possible that these represent chance findings. Replication of these findings using other data sets is needed. Further research is also needed to assess the impact of improved preventive care on disparities in clinically relevant outcomes among persons with low educational levels enrolled in HMOs.

In summary, our results should help allay concerns that HMOs might have an adverse impact on receipt of preventive care by less educated persons. Instead, the results suggest, in some instances, a modest salutary effect of HMOs. Further progress in addressing disparities in managed care will likely require performance assessment and quality improvement based on educational attainment. ${ }^{31}$
To read commentaries or to post a response to this article, see the online version at http://annfammed/cgi/content/full/1/2/90

Key words: Socioeconomic Factors, Health Maintenance Organizations, Ethnic Groups, Blacks, Hispanic Americans, Delivery of Health Care, Preventive Health Services

Submitted October 28, 2002; accepted November 4, 2002.

\section{Acknowledgments}

This research was funded by The Robert Wood Johnson Foundation under its Changes in Health Care Financing and Organization Initiative.

\section{REFERENCES}

1. Georges CA. President Clinton's new racial and ethnic health disparities initiative. Ethn Dis 1998;8:257-258.

2. Potosky AL, Breen N, Graubard BI, Parsons PE. The association between health care coverage and the use of cancer screening tests. Results from the 1992 National Health Interview Survey. Med Care $1998 ; 36: 257-270$

3. Hahn RA, Teutsch SM, Franks AL, Chang MH, Lloyd EE. The prevalence of risk factors among women in the United States by race and age, 1992-1994: opportunities for primary and secondary prevention. J Am Med Womens Assoc 1998;53:96-104,107.

4. Schneider EC, Cleary PD, Zaslavsky AM, Epstein AM. Racial disparity in influenza vaccination: does managed care narrow the gap between African Americans and whites? JAMA 2001;286:1455-1460.

5. Brechner RJ, Cowie CC, Howie LJ, Herman WH, Will JC, Harris MI. Ophthalmic examination among adults with diagnosed diabetes mellitus. JAMA 1993;270:1714-1718.

6. McDonald TP, Coburn AF. Predictors of prenatal care utilization. Soc Sci Med 1988;27:167-172.

7. Brook RH, Kamberg CJ, Lohr KN, Goldberg GA, Keeler EB, Newhouse JP. Quality of ambulatory care. Epidemiology and comparison by insurance status and income. Med Care 1990;28:392-433.

8. Kahn $\mathrm{KL}$, Pearson ML, Harrison ER, et al. Health care for black and poor hospitalized Medicare patients. JAMA 1994;271:1169-1174.

9. Epstein AM. Rolling down the runway: the challenges ahead for quality report cards. JAMA 1998;279:1691-1696.

10. Schneider EC, Riehl V, Courte-Wieneke S, Eddy DM, Sennett C. Enhancing performance measurement: NCQA's road map for a health information framework. JAMA 1999;282:1184-1190.

11. Ware JE Jr, Brook RH, Rogers WH, et al. Comparison of health outcomes at a health maintenance organisation with those of fee-forservice care. Lancet 1986;1:1017-1022.

12. Ware JE Jr, Bayliss MS, Rogers WH, Kosinski M, Tarlov AR. Differences in 4-year health outcomes for elderly and poor, chronically ill patients treated in $\mathrm{HMO}$ and fee-for-service systems. Results from the Medical Outcomes Study. JAMA 1996;276:1039-1047.

13. Hargraves JL, Cunningham PJ, Hughes RG. Racial and ethnic differences in access to medical care in managed care plans. Health Serv Res 2001;36:853-868.

14. Phillips KA, Mayer ML, Aday LA. Barriers to care among racial/ethnic groups under managed care. Health Aff (Millwood) 2000;19:65-75.

15. Kemper P, Blumenthal D, Corrigan JM, et al. The design of the community tracking study: a longitudinal study of health system change and its effects on people. Inquiry 1996;33:195-206.

16. Andersen RM. Revisiting the behavioral model and access to medical care: does it matter? J Health Soc Behav 1995;36:1-10. 
17. Ware JE Jr, Kosinski M, Keller SD. A 12-item short-form health survey. Construction of scales and preliminary tests of reliability and validity. Med Care 1996;34:220-233.

18. Jenkinson C, Layte $R$, Jenkinson $D$, et al. A shorter form health survey: can the SF-12 replicate results from the SF-36 in longitudinal studies? J Public Health Med 1997;19:179-186.

19. Research Triangle Institute. SUDAAN: Professional Software for Survey Data Analysis. Version 8.0. Research Triangle Park, NC: Research Triangle Institute; 2001.

20. Graubard BI, Korn EL. Predictive margins with survey data. Biometrics 1999;55:652-659.

21. Reschovsky JD. Do HMOs make a difference? Access to health care. Inquiry 1999;36:390-399.

22. Hellinger FJ. The effect of managed care on quality: a review of recent evidence. Arch Intern Med 1998;158:833-841.

23. Miller RH, Luft HS. Managed care plan performance since 1980. A literature analysis. JAMA 1994;271:1512-1519.

24. Reschovsky JD, Hargraves JL. Health care perceptions and experiences: it's not whether you are in an HMO, it's whether you think you are. Issue Brief Cent Stud Health Syst Change 2000;30:1-6.

25. King ES, Rimer BK, Trock B, Balshem A, Engstrom P. How valid are mammography self-reports? Am J Public Health 1990;80:13861388.

26. MacDonald R., Baken L, Nelson A, Nichol KL. Validation of selfreport of influenza and pneumococcal vaccination status in elderly outpatients. Am J Prev Med 1999;16:173-177.

27. Sawyer JA, Earp JA, Fletcher RH, Daye FF, Wynn TM. Accuracy of women's self-report of their last Pap smear. Am J Public Health 1989;79:1036-1037.
28. Zapka JG, Bigelow C, Hurley T, et al. Mammography use among sociodemographically diverse women: the accuracy of self-report. Am J Public Health 1996;86:1016-1021.

29. Robinson JC. The end of managed care. JAMA 2001;285:2622-2628.

30. Himmelstein DU, Woolhandler S, Hellander I, Wolfe SM. Quality of care in investor-owned vs not-for-profit HMOs. JAMA 1999;282:159163.

31. Fiscella K, Franks P, Gold MR, Clancy CM. Inequality in quality: addressing socioeconomic, racial, and ethnic disparities in health care. JAMA 2000;283:2579-2584.

32. Gornick ME. Disparities in Medicare Services: potential causes, plausible explanations, and recommendations. Health Care Financ Rev 2000;21:23-43.

33. Sellors J, Pickard L, Mahony JB, et al. Understanding and enhancing compliance with the second dose of hepatitis $B$ vaccine: a cohort analysis and a randomized controlled trial. CMAJ 1997;157:143148.

34. Wood D, Halfon N, Donald-Sherbourne C, et al. Increasing immunization rates among inner-city, African American children. A randomized trial of case management. JAMA 1998;279:29-34.

35. Weber $B E$, Reilly BM. Enhancing mammography use in the inner city. A randomized trial of intensive case management. Arch Intern Med 1997; 157:2345-2349.

36. Cigarette smoking among adults-United States, 1998. MMW/R Morb Mortal Wkly Rep 2000;49:881-884.

37. Kaplan GA, Keil JE. Socioeconomic factors and cardiovascular disease: a review of the literature. Circulation 1993;88:1973-1998.

38. Scott TL, Gazmararian JA, Williams MV, Baker DW. Health literacy and preventive health care use among Medicare enrollees in a managed care organization. Med Care 2002;40:395-404. 